\title{
Lung function measured by impulse oscillometry and spirometry following eucapnic voluntary hyperventilation
}

\author{
Kenneth W Rundell PhD, Tina M Evans PhD, Jennifer M Baumann MS, Matt F Kertesz BS
}

\begin{abstract}
KW Rundell, TM Evans, JM Baumann, MF Kertesz. Lung function measured by impulse oscillometry and spirometry following eucapnic voluntary hyperventilation. Can Respir J 2005;12(5):257-263.
\end{abstract}

BACKGROUND: The efficacy of impulse oscillometry (IOS) to measure airway calibre change is not fully established.

OBJECTIVES: To evaluate lung function change after eucapnic voluntary hyperventilation (EVH), and to compare IOS indices with spirometric maximal expiratory flow measurements.

METHODS: Twenty subjects (10 airway hyperresponsive [AHR+] and 10 normal [AHR-]) underwent IOS and spirometry before and for 15 min after 6 min EVH (inhaling $5 \% \mathrm{CO}_{2}, 21 \% \mathrm{O}_{2}$, balance $\mathrm{N}_{2}$ ) at a target ventilation of 30 times the baseline value of the forced expiratory volume in $1 \mathrm{~s}\left(\mathrm{FEV}_{1}\right)$ at $20^{\circ} \mathrm{C}$. AHR+ was defined by a fall in $\mathrm{FEV}_{1}$ of $10 \%$ or greater from baseline after a provoking challenge. Airway resistance at $5 \mathrm{~Hz}\left(\mathrm{R}_{5}\right)$, reactance at $5 \mathrm{~Hz}$, resonant frequency $\left(\mathrm{F}_{\text {res }}\right)$, area of reactance integrated from $5 \mathrm{~Hz}$ to $\mathrm{F}_{\text {res }}(\mathrm{AX})$, and $\mathrm{FEV}_{1}$ were determined.

RESULTS: No baseline spirometry values correlated with falls in $\mathrm{FEV}_{1}$. Baseline $\mathrm{R}_{5}$ and $A X$ values correlated with peak falls in $\mathrm{FEV}_{1}$ $(\mathrm{r}=-0.51$ and -0.46 , respectively; $\mathrm{P}<0.05)$. AHR + subjects demonstrated greater per cent peak falls in $\mathrm{FEV}_{1}$ than did AHR- subjects following EVH (30.6 $\pm 14.0 \%$ versus $7.5 \pm 2.6 \%$, respectively; $\mathrm{P}<0.05)$. Changes in $\mathrm{R}_{5}, \mathrm{~F}_{\text {res }}$, reactance and $\mathrm{AX}$ were greater for AHR+ subjects than for AHR- subjects and correlated with a fall in $\mathrm{FEV}_{1}$ $(\mathrm{r}=-0.74,-0.70,0.69$ and -0.73 , respectively; $\mathrm{P}<0.05)$. At a designated specificity of $80 \%$, the per cent change in $\mathrm{R}_{5}(50 \%$ or greater) and post-EVH AX ( $12 \mathrm{~cm} \mathrm{H}_{2} \mathrm{O} / \mathrm{L}$ or greater) yielded sensitivities to a $10 \%$ fall in $\mathrm{FEV}_{1}$ of $90 \%$.

CONCLUSION: IOS is an acceptable measure to determine AHR and can supplement spirometry in lung function evaluation.

Key Words: Airway hyperresponsiveness; Dry air; Eucapnic voluntary hyperpnea; Exercise-induced bronchoconstriction; Forced oscillation

$A$ lthough exercise-induced bronchoconstriction (EIB) has nisms remain elusive $(1-3)$. The response to EIB is most likely multimediated and dependent on the precise stimulus. For example, the pathophysiology of cold air-induced bronchoconstriction (4-6) involves different mediators than high particulate matter exposure $(7,8)$ or allergen-mediated bronchoconstriction (9). Likewise, there are differences of opinion concerning the most appropriate provoking challenge for diagnosis and what cutoff criteria should be employed for specific populations. Some studies have proposed a sports-specific challenge $(10,11)$, while others have suggested eucapnic voluntary hyperventilation (EVH) (12-16) or osmotic (17-19) challenges. Pharmacological challenges $(20,21)$ have been found to

\author{
Fonction pulmonaire mesurée par oscil- \\ lométrie à impulsion et spirométrie après \\ hyperventilation volontaire eucapnéique
}

HISTORIQUE : L'efficacité de l'oscillométrie à impulsion pour mesurer
les changements de calibre des voies respiratoires est plus ou moins bien
établie. OBJECTIF : Mesurer les changements de fonction pulmonaire après hyperventilation volontaire eucapnéique (HVE) et comparer les indices d'oscillométrie aux débits expiratoires de pointe obtenus par spirométrie. MÉTHODES : Vingt sujets (10 aux voies respiratoires hyperréactives [VRHR+] et 10 normaux [VRHR-]) ont subi une oscillométrie et une spirométrie avant, puis 15 minutes après 6 minutes d'HVE (inhalation de $\mathrm{CO}_{2}$ à $5 \%$, d'O$_{2}$ à $21 \%, \mathrm{~N}_{2}$ équilibré) à une ventilation cible de 30 fois la valeur de départ du VEMS à $20^{\circ} \mathrm{C}$. Les sujets VRHR+ étaient définis par une chute du VEMS de $10 \%$ ou plus comparativement au départ, après le test de provocation. La résistance respiratoire à $5 \mathrm{~Hz}\left(\mathrm{R}_{5}\right)$, la réactivité à $5 \mathrm{~Hz}$, la fréquence de résonance $\left(\mathrm{F}_{\text {res }}\right)$, la surface de réactivité intégrée de $5 \mathrm{~Hz}$ à $\mathrm{F}_{\text {res }}(\mathrm{AX})$ et le VEMS ont été déterminés.

RÉSULTATS : Aucune valeur de spirométrie de base n'était en corrélation avec les déclins du VEMS. Les valeurs $\mathrm{R}_{5}$ et $A X$ de base étaient en corrélation avec les déclins de pointe du VEMS $(r=-0,51$ et $-0,46$, respectivement; $\mathrm{p}<0,05)$. Les sujets HRVR+ ont présenté un pourcentage de déclin de pointe du VEMS plus marqué que les sujets HRVR- après l'hyperventilation $(30,6 \pm 14,0 \%$ versus $7,5 \pm 2,6 \%$, respectivement; $\mathrm{p}<0,05)$. Les changements de $\mathrm{R}_{5}$, de $\mathrm{F}_{\text {res }}$, de réactivité et d'AX ont été plus marqués chez les sujets HRVR+ que chez les sujets HRVR-et ont été en corrélation avec un déclin du VEMS $(r=-0,74,-0,70,0,69$ et $-0,73$, respectivement; $\mathrm{p}<0,05)$. À une spécificité désignée de $80 \%$, le changement de pourcentage du $\mathrm{R}_{5}$ ( $50 \%$ ou plus) et l'AX post-hyperventilation ( $12 \mathrm{~cm} \mathrm{H}_{2} \mathrm{O} / \mathrm{L}$ ou plus) ont donné des sensibilités de $90 \%$ pour ce qui est d'une baisse de $10 \%$ de VEMS.

CONCLUSION : L'oscillométrie à impulsion est une mesure acceptable pour déterminer l'hyperréactivité des voies respiratoires et peut compléter la spirométrie lors d'évaluation de la fonction pulmonaire.

be less sensitive for identifying EIB in athletes (15). The measurement most often used to determine airway hyperresponsiveness in athletes, regardless of the specific challenge, is a postchallenge $10 \%$ or greater fall in the forced expiratory volume in $1 \mathrm{~s}\left(\mathrm{FEV}_{1}\right)$, which is determined using spirometry from $5 \mathrm{~min}$ to $20 \mathrm{~min}$ after provocation $(10,22,23)$.

Impulse oscillometry (IOS) has been used to measure short-term changes in bronchial tone in bronchodilator tests (24), and has been shown to correlate with $\mathrm{FEV}_{1}$ (25-33) and airway resistance, which is determined by body plethysmography $(34,35)$. IOS applies brief, random pressure pulses of $5 \mathrm{~Hz}$ to $35 \mathrm{~Hz}$ generated by a small loudspeaker mounted in series or parallel to a pneumotachometer. The pressure impulses are superimposed to tidal breaths, and real-time recordings are 


\begin{tabular}{lcc}
$\begin{array}{l}\text { TABLE 1 } \\
\text { Subject demographics and per cent fall in forced } \\
\text { expiratory volume in 1 s after eucapnic voluntary } \\
\text { hyperventilation (mean } \mathbf{\pm} \text { SD) }\end{array}$ \\
\hline \multicolumn{3}{l}{ AHR- } \\
\hline $\mathrm{n}$ & 10 & AHR+ \\
Age (years) & $21.3 \pm 4.37$ & 10 \\
Weight $(\mathrm{kg})$ & $76.1 \pm 9.64$ & $25.5 \pm 8.73$ \\
Height $(\mathrm{cm})$ & $174.8 \pm 7.16$ & $173.0 \pm 6.71$ \\
Fall in FEV $(\%)$ & $7.5 \pm 2.59$ & $30.6 \pm 14.03$ \\
\hline
\end{tabular}

AHR Airway hyperresponsive

used to estimate total respiratory impedance. The two components of impedance are resistance and reactance. Bisgaard and Klug (25) have shown that reactance (X) at $5 \mathrm{~Hz}$ has the lowest intra- and between-individual variability, and has a sensitivity equal to that of airway conductance. Others have suggested that airway resistance at $5 \mathrm{~Hz}\left(\mathrm{R}_{5}\right)$ is sensitive to obstruction $(24,26,32)$. Goldman et al (36) demonstrated that the area of X integrated from $5 \mathrm{~Hz}$ to resonant frequency $\left(\mathrm{F}_{\text {res }}\right)$, otherwise known as AX, is sensitive for detecting changes in bronchomotor tone in adolescent asthmatics. Schmekel and Smith (31) found that the response in $\mathrm{F}_{\text {res }}$ has the most discriminative capacity to correctly diagnose asthma. Although the clinical efficacy of measuring respiratory impedance using IOS has been demonstrated, its use has not been widespread in assessing airflow obstruction (32).

In the present study, we compared airway responses with a 6 min EVH challenge using IOS and forced expiratory flow (FEF) manoeuvre values in airway hyperresponsive (AHR+) athletes and normal (AHR-) athletes and assessed the sensitivity and specificity of IOS to spirometry measures for identifying airway hyperresponsiveness. We correlated $\mathrm{R}_{5}, \mathrm{~F}_{\text {res }}, \mathrm{X}$ and $\mathrm{AX}$ to $\mathrm{FEV}_{1}$, and suggested cutoff criteria for these IOS measurements for determining airway hyperresponsiveness.

\section{METHODS}

Twenty subjects (five women and 15 men) volunteered to participate in the present study, which was approved by the Marywood University Institutional Review Board (Pennsylvania, USA). Table 1 provides subject demographic data. Ten subjects (four women and six men) were considered AHR + by a $10 \%$ or greater fall in $\mathrm{FEV}_{1}$ following $\mathrm{EVH}$, and 10 subjects (one woman and nine men) were considered AHR- by EVH.

The EVH protocol required subjects to breathe a compressed dry gas mixture $\left(21 \% \mathrm{O}_{2}, 5 \% \mathrm{CO}_{2}\right.$, balance $\left.\mathrm{N}_{2}\right)$ at a predetermined rate $\left(30 \times \mathrm{FEV}_{1}\right)$ for $6 \mathrm{~min}(12,14-16)$. Gas flowed from a cylinder through a calibrated rotameter (1110 Series Flowmeter, Brooks Instruments, USA) to three $300 \mathrm{~g}$ reservoir bags via highpressure tubing. From the reservoir bags, the gas was directed to the subject via a $35 \mathrm{~mm}$ breathing tube, two-way breathing valve and mouthpiece (Hans Rudolf, USA). Expired gas passed through a flow sensor and minute ventilation was recorded (Vmax Spectra, SensorMedics, USA). Inhaled gas during EVH was at laboratory temperature but completely dry. Ambient temperature, relative humidity and barometric pressure in the laboratory were $19.4 \pm 0.61^{\circ} \mathrm{C}, 16.1 \pm 3.22 \%$ and $722 \pm 7.8 \mathrm{mmHg}$, respectively.

Airway resistance and X were determined by IOS (MS-IOS, Jaeger, Germany) using the manufacturer's recommended techniques. Real-time recordings of mouth pressure and flow signals pulsed through the $5 \mathrm{~Hz}$ to $35 \mathrm{~Hz}$ spectrum were superimposed and displayed on a computer screen. Fast fourier transformation analysis calculated $\mathrm{R}_{5}$ ( $\mathrm{cm} \mathrm{H}_{2} \mathrm{O} / \mathrm{lps}$ [litres per second]), $\mathrm{X}$ ( $\left.\mathrm{cm} \mathrm{H}_{2} \mathrm{O} / \mathrm{lps}\right), \mathrm{F}_{\text {res }}$ $(\mathrm{Hz})$ and $\mathrm{AX}\left(\mathrm{cm} \mathrm{H}_{2} \mathrm{O} / \mathrm{L}\right)$.

Pulmonary function response to EVH was determined using spirometry immediately following the IOS manoeuvre. Forced vital capacity (FVC), $\mathrm{FEV}_{1}, \mathrm{FEV}_{1}$ to $\mathrm{FVC}$ ratio, and $\mathrm{FEF}$ through the middle portion of the vital capacity $\left(\mathrm{FEF}_{25-75}\right)$ were measured pre- and post-EVH. The procedure for all pulmonary function tests involved the following steps: three normal tidal volume breaths; maximal inhalation; forced maximal exhalation; and maximal inhalation as previously performed (16). All testing was completed using a calibrated, computerized pneumotachograph spirometer (Masterscope PC, Jaeger, Germany). Baseline pulmonary function was established by selecting the best of three resting pulmonary function tests. An individual measurement of maximum voluntary ventilation was obtained using a $12 \mathrm{~s}$ manoeuvre. Postchallenge pulmonary function was measured at $5 \mathrm{~min}, 10 \mathrm{~min}$ and $15 \mathrm{~min}$ after a challenge. If any postchallenge time point measurement was technically unacceptable, it was repeated.

Descriptive statistics for resting lung function were calculated for IOS and spirometry lung function measurements. Repeated measures ANOVA was used to analyze differences between post-EVH lung function measurements and between AHR+ and AHRgroups. Pearson Product Moment correlations were used to evaluate relationships between resting measurements and between postchallenge falls in $\mathrm{FEV}_{1}$, airway resistance and $\mathrm{X}$ measurements (determined using IOS). $\mathrm{P} \leq 0.05$ was considered significant.

\section{Baseline lung function}

\section{RESULTS}

Resting lung function variables obtained using IOS and maximal expiratory flow volume manoeuvres performed by 10 AHR+ and 10 AHR- subjects are presented in Table 2. Mean values for $\mathrm{FVC}, \mathrm{FEV}_{1}$, the $\mathrm{FEV}_{1}$ to $\mathrm{FVC}$ ratio and $\mathrm{FEF}_{25-75}$ were within normal limits for both groups. The $\mathrm{FEV}_{1}$ values of two AHR+ subjects were $80 \%$ or below the values that were predicted. The $\mathrm{FEF}_{25-75}$ values of five AHR+ subjects and two AHRsubjects were $70 \%$ or below the predicted values. One subject demonstrated an $\mathrm{FEV}_{1}$ to $\mathrm{FVC}$ ratio of $66 \%$.

No resting spirometric measures were related to post-EVH falls in $F_{E V}$. Resting $R_{5}$ and $A X$ values were significantly correlated with peak post-EVH falls in $\mathrm{FEV}_{1}(\mathrm{r}=-0.51$ and -0.46 , respectively; $\mathrm{P}<0.05$ ). No significant correlations were identified between peak fall in $\mathrm{FEV}_{1}$ and resting $\mathrm{F}_{\text {res }}$ or $\mathrm{X}$ values $(\mathrm{r}=-0.30$ and 0.41 , respectively). Presented in Table 3 are correlation coefficients to post-EVH peak falls in $\mathrm{FEV}_{1}$, as well as baseline cutoff criteria, sensitivity and predictive values for $80 \%$ specificity.

\section{Airway response to EVH}

Peak post-EVH measurements from IOS were significantly greater than baseline values for AHR+ and AHR- subjects $(\mathrm{P}<0.05)$. Baseline IOS measurements were not different between AHR+ and AHR- subjects; however, postchallenge peak IOS values were different between subject groups (Figure $1 ; \mathrm{P}<0.05$ ). Per cent changes for AHR + and AHR- subjects in $R_{5}, F_{\text {res }}, X$ and $A X$ were 70.3 versus $37.9,82.6$ versus 48.6, 175.9 versus 70.8 , and 567.8 versus 267.0 , respectively. When computed as a per cent change from baseline, only the per cent change in peak $R_{5}$ was significantly greater for AHR+ subjects $(P<0.05) ; F_{\text {res }}, X$ and AX per cent changes were not 


\section{TABLE 2}

Baseline values for spirometry and impulse oscillometry*

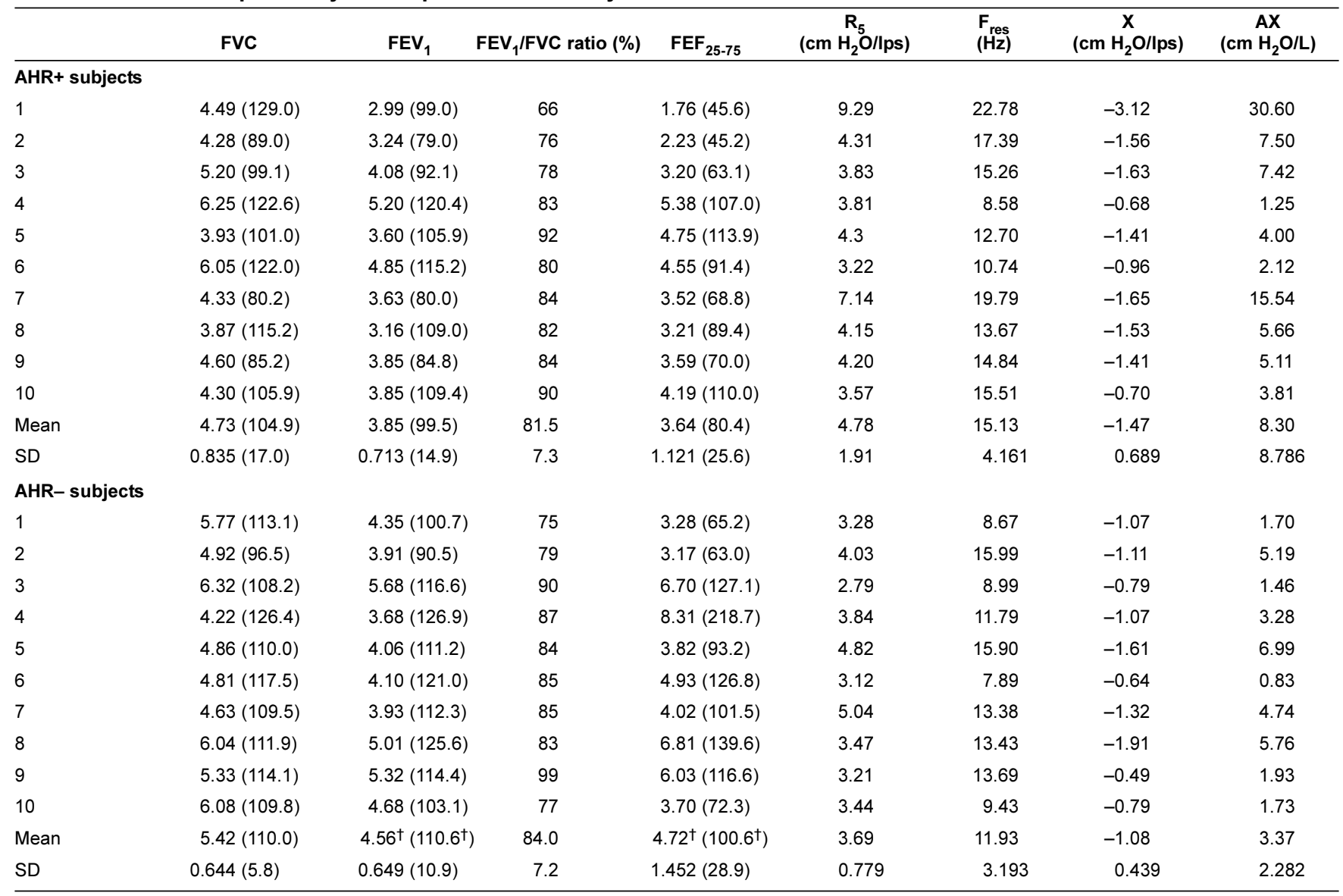

${ }^{*}$ Per cent predicted values are in parentheses. ${ }^{\dagger}$ Significant difference between airway hyperresponsive (AHR+) and normal (AHR-) subjects ( $\left.P<0.05\right)$. AX Area of reactance integrated from $5 \mathrm{~Hz}$ to resonant frequency $\left(F_{\text {res }}\right) ; F E F_{25-75}$ Forced expiratory flow through the middle portion of the vital capacity; FEV $F_{1}$ Forced expiratory volume in $1 \mathrm{~s}$; FVC Forced vital capacity; $R_{5}$ Airway resistance at $5 \mathrm{~Hz}$; $X$ Reactance

significantly different between AHR groups. The pattern of change in $R_{5}$ values at 10 min after EVH was similar to that observed for $\mathrm{FEV}_{1}$ (Figure 2); however, resistance at $15 \mathrm{~min}$ after EVH was not different between groups.

Relationship between spirometry and IOS

Peak increase in $R_{5}$ was significantly correlated with peak increases in $\mathrm{F}_{\text {res, }}, \mathrm{X}$ and $\mathrm{AX}(\mathrm{r}=0.79,-0.94$ and 0.98 , respectively; $\mathrm{P}<0.05)$. Peak increase in $\mathrm{F}_{\text {res }}$ was significantly correlated with peak increases in $\mathrm{X}$ and $\mathrm{AX}(\mathrm{r}=-0.83$ and 0.84 , respectively; $\mathrm{P}<0.05)$. Peak increase in $\mathrm{X}$ was significantly correlated to peak $\mathrm{AX}(\mathrm{r}=-0.96 ; \mathrm{P}<0.05)$. Per cent peak fall in $\mathrm{FEV}_{1}$ was significantly correlated with peak increases in $\mathrm{R}_{5}, \mathrm{~F}_{\text {res }}, \mathrm{X}$ and AX expressed as raw values $(r=-0.74,-0.70,0.69$ and -0.73 , respectively; $\mathrm{P}<0.05$ ) (Figure 3 ) and to per cent change (from baseline) in $\mathrm{R}_{5}, \mathrm{~F}_{\text {res }}, \mathrm{X}$ and $\mathrm{AX}(\mathrm{r}=-0.66,-0.47,-0.57$ and -0.46 , respectively; $\mathrm{P}<0.05$ ) (Figure 4). Per cent peak fall in $\mathrm{FEF}_{25-75}$ was significantly correlated with peak increases in $R_{5}$, $\mathrm{F}_{\text {res }}, \mathrm{X}$ and $\mathrm{AX}$ as raw values $(\mathrm{r}=-0.57,-0.63,0.58$ and -0.57 , respectively; $\mathrm{P}<0.05$ ) and to per cent increases in $\mathrm{R}_{5}, \mathrm{~F}_{\text {res }}, \mathrm{X}$ and AX ( $\mathrm{r}=-0.58,-0.49,-0.56$ and -0.4 , respectively; $\mathrm{P}<0.05)$.

\section{DISCUSSION}

EVH is a widely accepted provocation challenge for EIB among high-level athletes. In fact, $\mathrm{EVH}$ is the challenge
TABLE 3

Relationship between impulse oscillometry variables and peak falls in forced expiratory volume in $1 \mathrm{~s}$ following eucapnic voluntary hyperventilation (EVH)

\begin{tabular}{|c|c|c|c|c|c|c|c|c|}
\hline Variable & $\mathbf{n}$ & Cutoff & $\mathbf{r}$ & $\begin{array}{c}\text { Sens } \\
(\%)\end{array}$ & $\begin{array}{c}\text { Spec } \\
(\%)\end{array}$ & $\begin{array}{l}\text { PPV } \\
\text { (\%) }\end{array}$ & $\begin{array}{c}\text { NPV } \\
(\%)\end{array}$ & $\begin{array}{l}\text { TA } \\
\text { (\%) }\end{array}$ \\
\hline Baseline $R_{5}$ & 20 & $4.0 \mathrm{~cm} \mathrm{H}_{2} \mathrm{O} / \mathrm{lps}$ & $-0.51^{*}$ & 60 & 80 & 75 & 67 & 70 \\
\hline Baseline $F_{\text {res }}$ & 20 & $14 \mathrm{~Hz}$ & -0.30 & 60 & 80 & 75 & 67 & 70 \\
\hline Baseline $X$ & 20 & $-1.30 \mathrm{~cm} \mathrm{H}_{2} \mathrm{O} / \mathrm{ps}$ & 0.41 & 70 & 80 & 78 & 73 & 75 \\
\hline Baseline AX & 20 & $5.5 \mathrm{~cm} \mathrm{H}_{2} \mathrm{O} / \mathrm{L}$ & $-0.46^{*}$ & 60 & 80 & 75 & 67 & 70 \\
\hline Post-EVH $\mathrm{R}_{5}$ & 20 & $6.0 \mathrm{~cm} \mathrm{H}_{2} \mathrm{O} / \mathrm{lps}$ & $-0.74^{\star}$ & 80 & 80 & 80 & 80 & 80 \\
\hline $\begin{array}{r}\text { Post-EVH } \mathrm{R}_{5} \\
\text { (\% change) }\end{array}$ & 20 & $50 \%$ & $-0.66^{*}$ & 90 & 80 & 82 & 89 & 85 \\
\hline Post-EVH $F_{\text {res }}$ & 20 & $19 \mathrm{~Hz}$ & $-0.70^{*}$ & 80 & 80 & 80 & 80 & 80 \\
\hline $\begin{array}{c}\text { Post-EVH F } F_{\text {res }} \\
\text { (\% change) }\end{array}$ & 20 & $65 \%$ & $-0.47^{*}$ & 50 & 80 & 71 & 62 & 65 \\
\hline Post-EVH X & 20 & $-2.0 \mathrm{~cm} \mathrm{H}_{2} \mathrm{O} / \mathrm{lps}$ & $0.69^{*}$ & 80 & 80 & 80 & 80 & 80 \\
\hline $\begin{array}{l}\text { Post-EVH X } \\
\text { (\% change) }\end{array}$ & 20 & $90 \%$ & $-0.57^{*}$ & 80 & 80 & 80 & 80 & 80 \\
\hline Post-EVH AX & 20 & $12 \mathrm{~cm} \mathrm{H}_{2} \mathrm{O} / \mathrm{L}$ & $-0.73^{*}$ & 90 & 80 & 82 & 89 & 85 \\
\hline $\begin{array}{r}\text { Post-EVH AX } \\
\text { ( } \% \text { change) }\end{array}$ & 20 & $300 \%$ & $-0.46^{*}$ & 40 & 80 & 67 & 57 & 60 \\
\hline
\end{tabular}

Cutoff values, sensitivity (Sens), positive predictive value (PPV), negative predictive value (NPV) and test accuracy (TA) were calculated for impulse oscillometry parameters for a specificity (Spec) of $80 \%$. *Indicates a significant correlation to post-EVH peak fall in forced expiratory volume in $1 \mathrm{~s}$ $(P<0.05)$. AX Area of reactance integrated from $5 \mathrm{~Hz}$ to resonant frequency $\left(F_{\text {res }}\right)$; Ips Litres per second; $R_{5}$ Airway resistance at $5 \mathrm{~Hz} ; X$ Reactance 

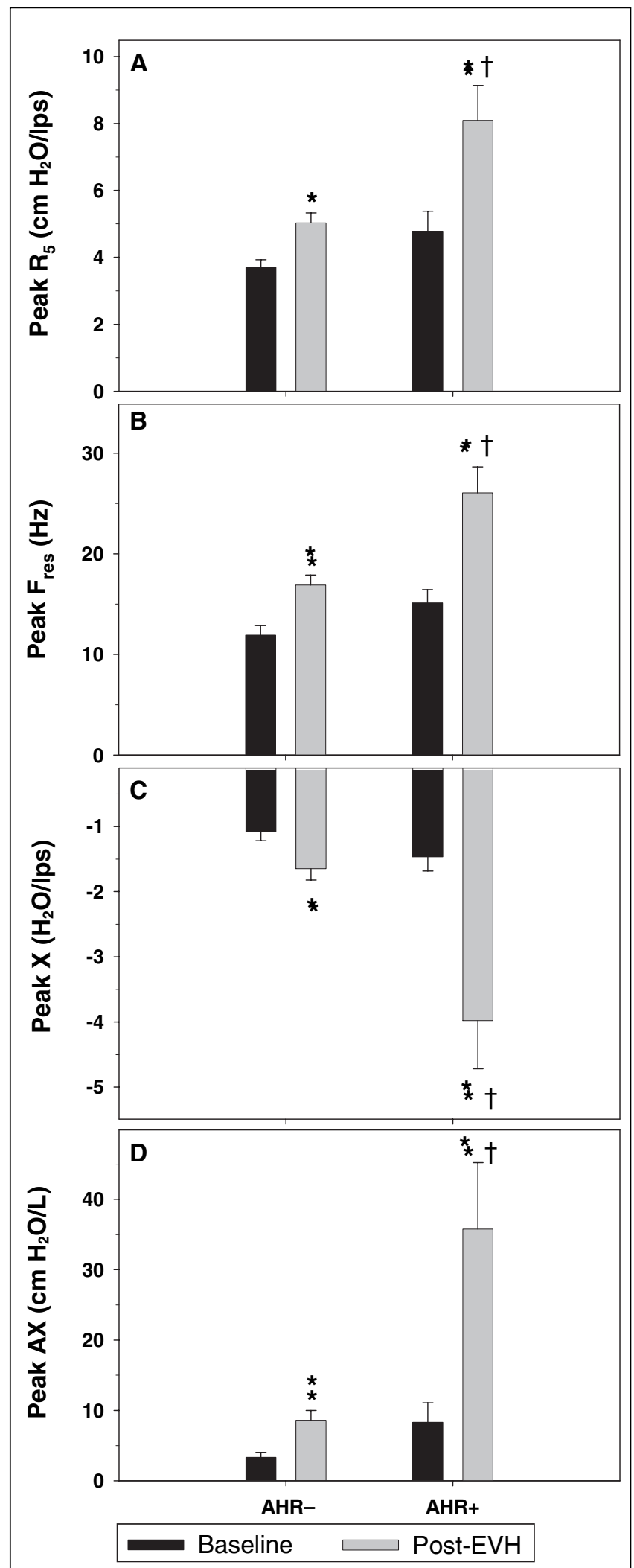

Figure 1) Posteucapnic voluntary hyperventilation (EVH) values for airway resistance at $5 \mathrm{~Hz}\left(R_{5}\right)$, resonant frequency $\left(F_{\text {res }}\right)$, reactance $(X)$ and area of reactance integrated from $5 \mathrm{~Hz}$ to $F_{\text {res }}(\mathrm{AX})$ were significantly greater for baseline values for both airway hyperresponsive $(\mathrm{AHR}+)$ and normal $(\mathrm{AHR}-)$ subjects $(* \mathrm{P}<0.05)$, and were greater for AHR+ subjects than for AHR- subjects $\left({ }^{\dagger} \mathrm{P}<0.05\right)$
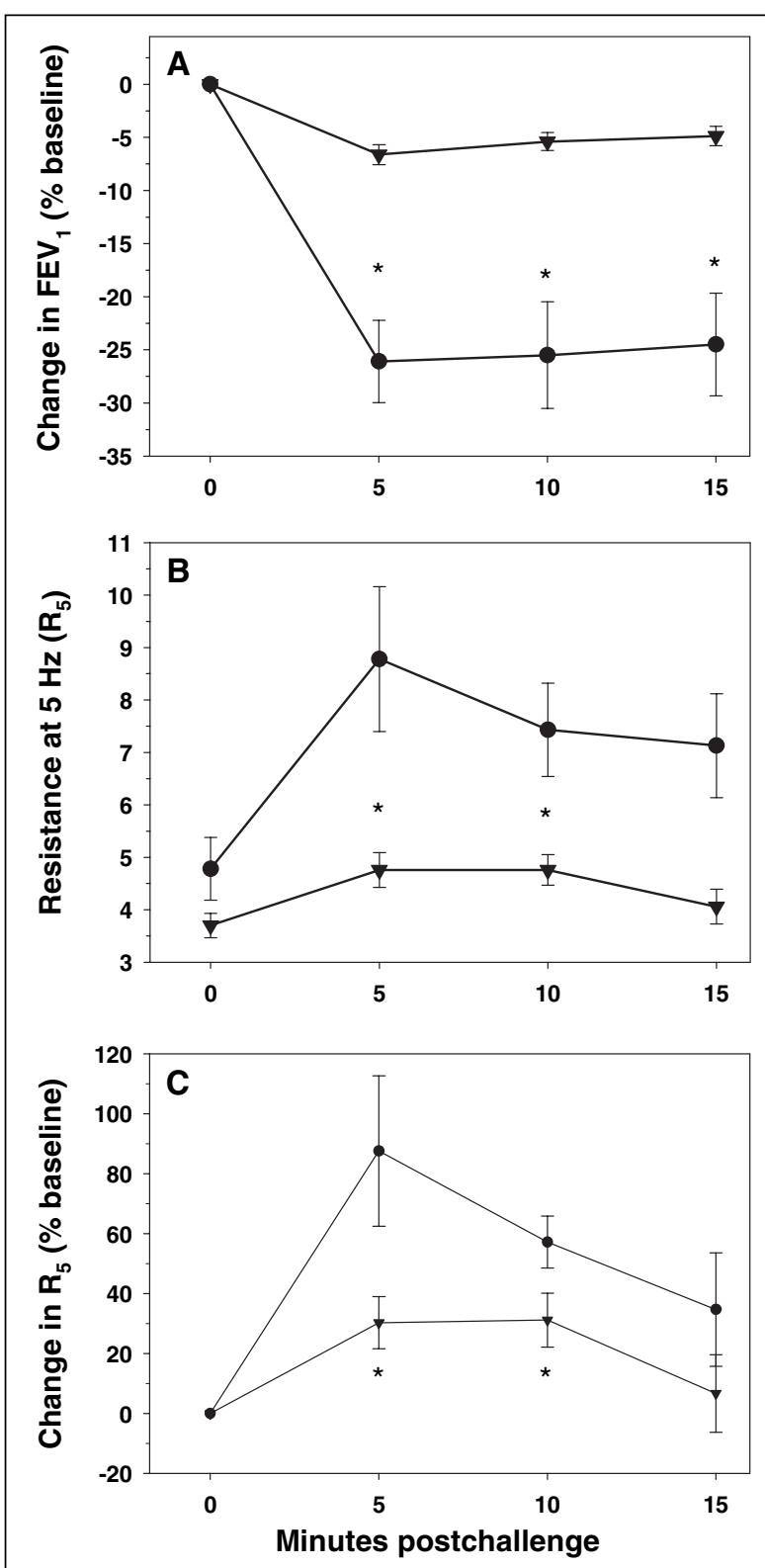

Figure 2) The persistence of airway obstruction in airway hyperresponsive $(\mathrm{AHR}+)$ versus normal (AHR-) subjects over 15 min after the completion of eucapnic voluntary hyperventilation measured by per cent change in forced expiratory volume in $1 \mathrm{~s}\left(\mathrm{FEV}_{1}\right.$; panel $\left.\mathrm{A}\right)$, airway resistance at $5 \mathrm{~Hz}\left(R_{5}\right.$; panel $\left.\mathbf{B}\right)$, and per cent change in $R_{5}$ (panel $\left.\mathbf{C}\right)$

recommended by the International Olympic Committee Medical Commission Independent Panel to evaluate EIB in Olympic athletes (14-16). In the present study, we compared postchallenge $\mathrm{FEV}_{1}$ measurements obtained from maximal expiratory flow volume manoeuvres with measurements of airway impedance obtained from IOS during tidal breathing in AHR+ and AHR- subjects. Our results demonstrated that IOS provides a reliable method of evaluating airway obstruction as defined from spirometry measurements in a collegeaged athletic population. We identified useful criteria for measuring AHR using IOS. Nine of the 10 subjects with a $10 \%$ or greater fall in $\mathrm{FEV}_{1}$ demonstrated a greater than $50 \%$ 


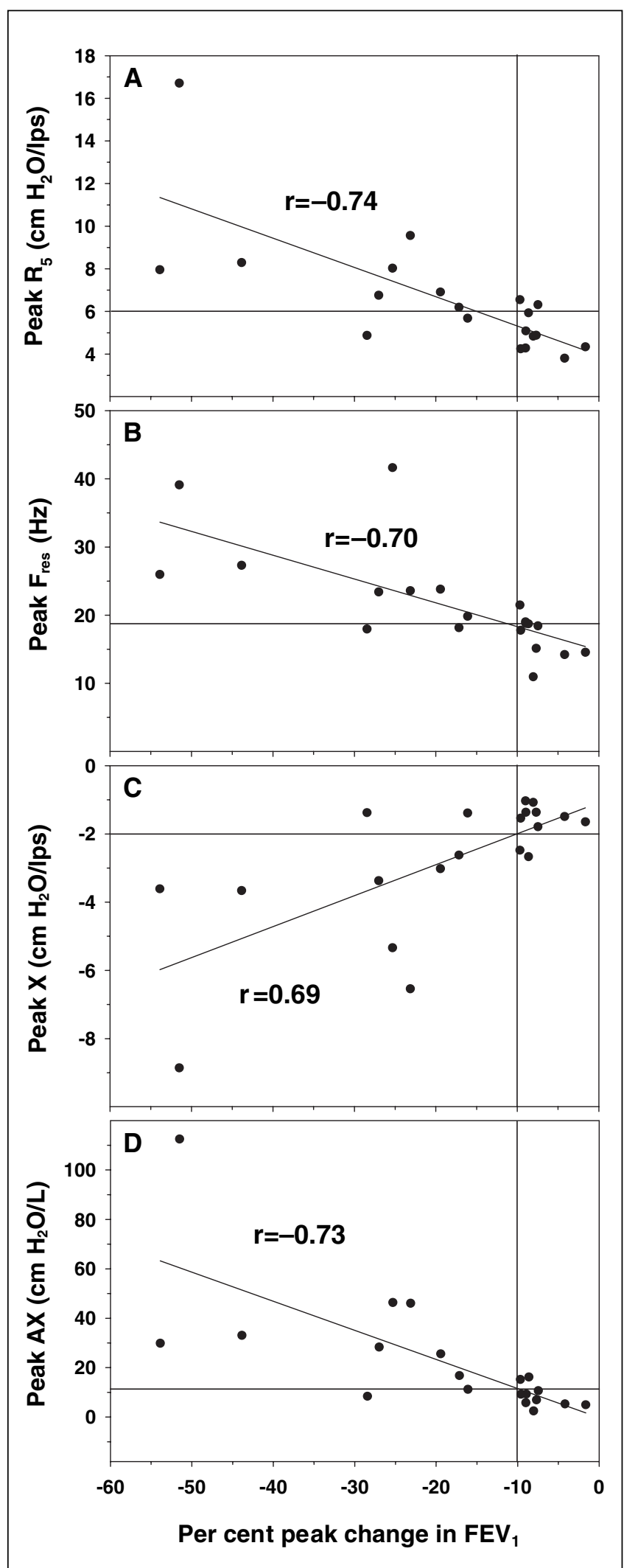

Figure 3) Peak changes in airway resistance at $5 \mathrm{~Hz}\left(R_{5}\right)(\mathrm{A})$, resonant frequency $\left(F_{\text {res }}\right)(\mathbf{B})$, reactance $(X)$ at $5 \mathrm{~Hz}(\mathrm{C})$, and area of reactance integrated from $5 \mathrm{~Hz}$ to $\mathrm{F}_{\text {res }}$ (AX) (D) after eucapnic voluntary hyperventilation were significantly correlated to peak per cent change in forced expiratory volume in $1 \mathrm{~s}\left(\mathrm{FEV}_{1}\right)(\mathrm{P}<0.05)$. Cutoff reference lines indicate a $10 \%$ fall in $\mathrm{FEV}_{1}$ and $80 \%$ specificity for impulse oscillometry indices. Sensitivities were $80 \%$ for $R_{5}, F_{\text {res }}$ and $X$, and $90 \%$ for $\mathrm{AX}$

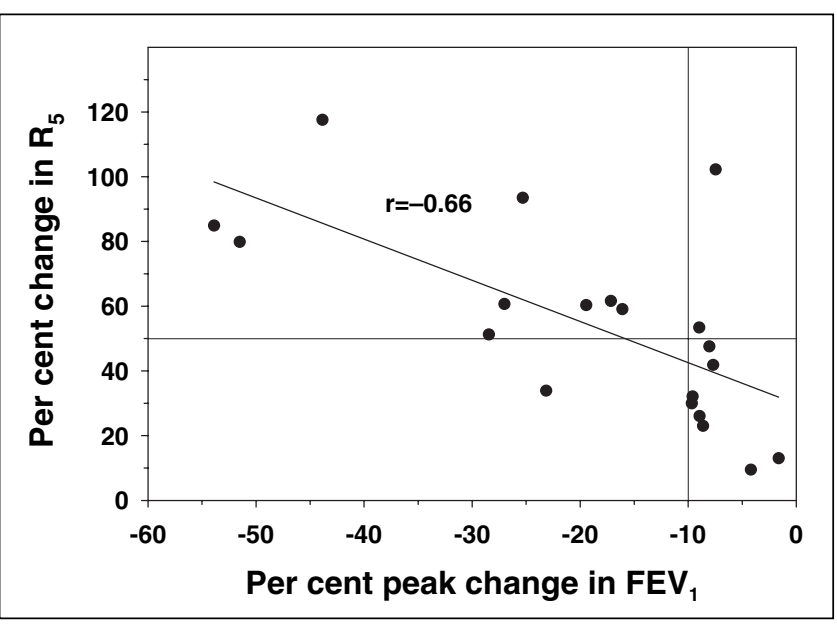

Figure 4) Peak per cent change in airway resistance at $5 \mathrm{~Hz}\left(R_{5}\right)$ was significantly correlated to peak per cent change in forced expiratory volume in $1 \mathrm{~s}\left(\mathrm{FEV}_{1}\right)$. At $80 \%$ specificity, a $50 \%$ change in $\mathrm{R}_{5}$ demonstrated high sensitivity, only missing one subject positive for $\mathrm{FEV}_{1}$, indicating reasonable agreement with per cent fall in $\mathrm{FEV}_{1}$

increase from baseline in $\mathrm{R}_{5}$ (or had a postchallenge value of $5.5 \mathrm{~cm} \mathrm{H} 2 \mathrm{O} / \mathrm{lps}$ ). Moreover, an additional three subjects who were borderline AHR- by FEV 1 demonstrated elevated $\mathrm{R}_{5}$ values consistent with airway obstruction, suggesting that the forced expiratory manoeuvre may mask changes in airway tone.

We used postchallenge falls from baseline in $\mathrm{FEV}_{1}$ as the 'gold standard' indirect measure of changes in airway calibre after EVH because it is the most widely used index of AHR $(22,23) . \mathrm{FEF}_{25-75}$ was also used as an indication of airway obstruction; however, postchallenge $\mathrm{FEF}_{25-75}$ is only valid when vital capacity is unaltered $(16,37)$. In the present study, vital capacity remained relatively unchanged; therefore, comparisons of $\mathrm{FEF}_{25-75}$ with IOS indices were made. Peak falls in $\mathrm{FEF}_{25-75}$ were highly correlated to peak falls in $\mathrm{FEV}_{1}$. A significant response to EVH was obtained; mean postchallenge per cent peak falls for respective AHR+ and AHR- subjects were $30.6 \pm 14.0 \%$ and $7.5 \pm 2.6 \%$ for $\mathrm{FEV}_{1}$, and $50.7 \pm 17.8 \%$ and $22.4 \pm 7.7 \%$ for $\mathrm{FEF}_{25-75}$. The falls for the AHR- group were substantially greater than expected. Rundell et al (16) obtained a fall of $4.7 \pm 3.2 \%$ after EVH in 21 AHR- subjects, suggesting that underlying hyperreactivity could have been present in our control population; only two subjects in the AHR- group had peak falls in $\mathrm{FEV}_{1}$ of less than $7.5 \%$. Interestingly, those two subjects were the only subjects that demonstrated post-EVH increases in $\mathrm{R}_{5}$ of less than $20 \%(9.5 \%$ and $13.0 \%$; Figure 4 ). The cutoff value to define reversible airway obstruction is usually based on the mean plus two standard deviations of the response in healthy subjects. Although we used the widely accepted cutoff of a $10 \%$ fall in $\mathrm{FEV}_{1}$, values of $7.5 \%$ and $6.5 \%$ have been suggested to define AHR in elite cold weather athletes (11) and elite Finnish runners (21), respectively.

Respiratory impedance was evaluated using IOS and compared with $\mathrm{FEV}_{1}$ and $\mathrm{FEF}_{25-75}$ values obtained from spirometry. The IOS manoeuvre involves tidal breathing for $20 \mathrm{~s}$ to $30 \mathrm{~s}$ while respiratory flow is overlaid with pulses emitted from a loudspeaker. Based on the airflow response, impedance estimated as the spectral ratio between pressure and flow through $5 \mathrm{~Hz}$ to $35 \mathrm{~Hz}$ is resolved into resistance and X. Debate exists concerning which is more discriminating when detecting airway 
obstruction; however, it is widely accepted that IOS measurements are frequency-dependent with the pronounced changes occurring at lower frequencies $(24,25,38,39)$. Some studies have shown that resistance at $5 \mathrm{~Hz}$ significantly correlates with baseline $\mathrm{FEV}_{1}(26,28)$, postmethacholine challenge $\mathrm{FEV}_{1}$ $(25,27,32)$ or postbronchodilator FEV $_{1}$ values $(24,33,38)$. Others have suggested that $\mathrm{X}$ at $5 \mathrm{~Hz}$ is most sensitive to changes in airway calibre. Buhr et al (35) found that X determined by oscillometry significantly correlated with airway resistance determined using body plethysmography $(\mathrm{r}=0.86)$, and Ortiz and Menendez (30) suggested that a 30\% change in $\mathrm{X}$ following a bronchodilator challenge is approximately equal to a $12 \%$ increase in $\mathrm{FEV}_{1}$. Goldman et al (36) proposed that the integrated $\mathrm{X}$ over a range of low frequencies $\left(5 \mathrm{~Hz}\right.$ to $\left.\mathrm{F}_{\text {res }}\right)$ provides meaningful evidence of airflow obstruction beyond the sensitivity of spirometry. Still others have shown that $\mathrm{F}_{\text {res }}$ correlates best with baseline $\mathrm{FEV}_{1}(\mathrm{r}=-0.55)$ (28). Schmekel and Smith (31) found that the change in $\mathrm{F}_{\text {res }}$ following $\mathrm{EVH}$ correctly diagnosed asthma with $89 \%$ sensitivity and 100\% specificity. Our study showed that the changes from baseline in $\mathrm{R}_{5}, \mathrm{~F}_{\text {res }}, \mathrm{X}$ and $\mathrm{AX}$ following EVH were significantly greater for $\mathrm{AHR}+$ subjects than for AHR- subjects. Moreover, all were significantly correlated with post-EVH change in $\mathrm{FEV}_{1}$, with highest sensitivities $(90 \%$ at predetermined specificities of $80 \%$ ) for per cent change in $\mathrm{R}_{5}$ and absolute postchallenge $\mathrm{AX}\left(\mathrm{cm} \mathrm{H}_{2} \mathrm{O} / \mathrm{L}\right)$.

AHR in asthmatics is often associated with abnormalities in baseline lung function. In the present group of athletic subjects, baseline $\mathrm{FEV}_{1}$ was within a normal range; only two subjects demonstrated values that were $80 \%$ or less than that predicted, and $\mathrm{FEF}_{25-75}$ values were at or below $70 \%$ of the predicted values for five AHR+ subjects and two AHR- subjects. Baseline values in $\mathrm{FEF}_{25-75}$ were strongly correlated to

\section{REFERENCES}

1. Rundell KW, Jenkinson DM. Exercise-induced bronchospasm in the elite athlete. Sports Med 2002;32:583-600.

2. Anderson SD, Daviskas E. The mechanism of exercise-induced asthma is... J Allergy Clin Immunol 2000;106:453-9.

3. Bar-Yishay E, Godfrey S. Mechanisms of exercise-induced asthma. Lung 1984;162:195-204.

4. Sue-Chu M, Larsson L, Moen T, Rennard SI, Bjermer L. Bronchoscopy and bronchoalveolar lavage findings in cross-country skiers with and without "ski asthma". Eur Respir J 1999;13:626-32.

5. Karjalainen EM, Lairinen A, Sue-Chu M, Altraja A, Bjermer L, Lairinen LA. Evidence of airway inflammation and remodeling in ski athletes with and without bronchial hyperresponsiveness to methacholine. Am J Respir Crit Care Med 2000;161:2086-91.

6. Davis MS, Lockard AJ, Marlin DJ, Freed AN. Airway cooling and mucosal injury during cold weather exercise. Equine Vet J 2002;(Suppl 34):413-6.

7. Rundell KW. Pulmonary function decay in women ice hockey players: Is there a relationship to ice rink air quality? Inhal Toxicol 2004;16:117-23.

8. Rundell KW, Spiering BA, Evans TM, Baumann JM. Baseline lung function, exercise-induced bronchoconstriction, and asthma-like symptoms in elite women ice hockey players. Med Sci Sports Exerc 2004;36:405-10.

9. Drazen JM. Leukotrienes as mediators of airway obstruction. Am J Respir Crit Care Med 1998;158:S193-200.

10. Rundell KW, Wilber RL, Szmedra L, Jenkinson DM, Mayers LB, Im J. Exercise-induced asthma screening of elite athletes: Field versus laboratory exercise challenge. Med Sci Sports Exerc 2000;32:309-16.

11. Rundell KW, Im J, Mayers LB, Wilber RL, Szmedra L, Schmitz HR. Self-reported symptoms and exercise-induced asthma in the elite athlete. Med Sci Sports Exerc 2001;33:208-13.

12. Argyros GJ, Roach JM, Hurwitz KM, Eliasson AH, Phillips YY. Eucapnic voluntary hyperventilation as a bronchoprovocation baseline values in $\mathrm{FEV}_{1}$ and, similar to the results of others $(24,28,29,38,40)$, we observed significant correlations between baseline spirometric parameters and baseline IOS measurements. No baseline lung functions determined using spirometry correlated with postexercise falls in $\mathrm{FEV}_{1}$; however, significant correlations with peak post-EVH falls in $\mathrm{FEV}_{1}$ were observed for baseline $R_{5}$ and $A X$ values.

Currently, there is no consensus on IOS criteria for the diagnosis and grading of airway obstruction (24). In the present study, we provided cutoff criteria, sensitivity and predictive values for $80 \%$ specificity to the gold standard of $10 \%$ change in $\mathrm{FEV}_{1}$ after EVH. We identified significant correlations of peak falls in $\mathrm{FEV}_{1}$ to post-EVH increases in $\mathrm{R}_{5}, \mathrm{~F}_{\text {res }}, \mathrm{X}$ and $\mathrm{AX}$. Our study supports $\mathrm{R}_{5}$ per cent change and change in $\mathrm{AX}$ ( $\mathrm{cm} \mathrm{H}_{2} \mathrm{O} / \mathrm{L}$ ) as the most sensitive indices of airway obstruction; a $50 \%$ increase in $\mathrm{R}_{5}$ and a postchallenge $A X$ value of greater than $12 \mathrm{~cm} \mathrm{H}_{2} \mathrm{O} / \mathrm{L}$ provided $90 \%$ sensitivity to peak fall in $\mathrm{FEV}_{1}$. This is in agreement with Goldman et al (36), who demonstrated that inspiratory $\mathrm{R}_{5}$ and $\mathrm{AX}$ are most sensitive to daily changes in respiratory status.

In summary, substantial and significant changes in $\mathrm{R}_{5}, \mathrm{~F}_{\mathrm{res}}, \mathrm{X}$ and $\mathrm{AX}$ were noted after $\mathrm{EVH}$, and all were significantly correlated with post-EVH falls in $\mathrm{FEV}_{1}$. We defined acceptable cutoff criteria for determining postchallenge airway obstruction for per cent change in $R_{5}$ and increases in $A X$. The sensitivities of these measures to post-EVH falls in $\mathrm{FEV}_{1}$ support the use of IOS as an acceptable method for diagnosis of airway obstruction and AHR; these measures can be used with patients where accurate and reliable spirometry measures may be difficult to obtain.

ACKNOWLEDGEMENTS: The authors would like to thank Barry Spiering for technical assistance in data collection. This study was supported in part by VIASYS Healthcare.

technique: Development of a standardized dosing schedule in asthmatics. Chest 1996;109:1520-4.

13. Mannix ET, Manfredi F, Farber MO. A comparison of two challenge tests for identifying exercise-induced bronchospasm in figure skaters. Chest 1999;115:649-53.

14. Anderson SD, Argyros GJ, Magnussen H, Holzer K. Provocation by eucapnic voluntary hyperpnoea to identify exercise induced bronchoconstriction. Br J Sports Med 2001;35:344-7.

15. Holzer K, Anderson SD, Douglass J. Exercise in elite summer athletes: Challenges for diagnosis. J Allergy Clin Immunol 2002;110:374-80.

16. Rundell KW, Anderson SD, Spiering BA, Judelson DA. Field exercise vs laboratory eucapnic voluntary hyperventilation to identify airway hyperresponsiveness in elite cold weather athletes. Chest 2004;125:909-15.

17. Smith CM, Anderson SD. Inhalation provocation tests using nonisotonic aerosols. J Allergy Clin Immunol 1989;84:781-90.

18. Brannan JD, Koskela H, Anderson SD, Chew N. Responsiveness to mannitol in asthmatic subjects with exercise- and hyperventilationinduced asthma. Am J Respir Crit Care Med 1998;158:1120-6.

19. Holzer K, Anderson SD, Chan HK, Douglass J. Mannitol as a challenge test to identify exercise-induced bronchoconstriction in elite athletes. Am J Respir Crit Care Med 2003;167:534-7.

20. Lin CC, Wu JL, Huang WC, Lin CY. A bronchial response comparison of exercise and methacholine in asthmatic subjects. J Asthma 1991;28:31-40.

21. Helenius IJ, Tikkanen HO, Haahtela T. Occurrence of exercise induced bronchospasm in elite runners: Dependence on atopy and exposure to cold air and pollen. Br J Sports Med 1998;32:125-9.

22. Sterk PJ, Fabbri LM, Quanjer PH, et al. Airway responsiveness. Standardized challenge testing with pharmacological, physical and sensitizing stimuli in adults. Report Working Party Standardization of Lung Function Tests, European Community for Steel and Coal. 
Official Statement of the European Respiratory Society. Eur Respir J Suppl 1993;16:53-83.

23. Crapo RO. Pulmonary-function testing. N Engl J Med 1994;331:25-30.

24. Delacourt C, Lorino H, Herve-Guillot M, Reinert P, Harf A, Housset B. Use of the forced oscillation technique to assess airway obstruction and reversibility in children. Am J Respir Crit Care Med 2000;161:730-6.

25. Bisgaard $\mathrm{H}$, Klug B. Lung function measurement in awake young children. Eur Respir J 1995;8:2067-75.

26. Carvalhaes-Neto N, Lorino H, Gallinari C, et al. Cognitive function and assessment of lung function in the elderly. Am J Respir Crit Care Med 1995;152:1611-5.

27. Duiverman EJ, Neijens HJ, Van der Snee-van Smaalen M, Kerrebijn KF. Comparison of forced oscillometry and forced expirations for measuring dose-related responses to inhaled methacholine in asthmatic children. Bull Eur Physiopathol Respir 1986;22:433-6.

28. Kim CW, Kim JS, Park JW, Hong CS. Clinical applications of forced oscillation techniques (FOT) in patients with bronchial asthma. Korean J Intern Med 2001;16:80-6.

29. Lebecque P, Desmond K, Swartebroeckx Y, Dubois P, Lulling J, Coates A. Measurement of respiratory system resistance by forced oscillation in normal children: A comparison with spirometric values. Pediatr Pulmonol 1991;10:117-22

30. Ortiz G, Menendez R. The effects of inhaled albuterol and salmeterol in 2- to 5-year-old asthmatic children as measured by impulse oscillometry. J Asthma 2002;39:531-6.

31. Schmekel B, Smith HJ. The diagnostic capacity of forced oscillation and forced expiration techniques in identifying asthma by isocapnic hyperpnoea of cold air. Eur Respir J 1997;10:2243-9.
32. Vink GR, Arets HG, van der Laag J, van der Ent CK. Impulse oscillometry: A measure for airway obstruction. Pediatr Pulmonol 2003;35:214-9.

33. Zerah F, Lorino AM, Lorino H, Harf A, Macquin-Mavier I. Forced oscillation technique vs spirometry to assess bronchodilatation in patients with asthma and COPD. Chest 1995;108:41-7.

34. Klug B, Bisgaard H. Specific airway resistance, interrupter resistance, and respiratory impedance in healthy children aged 2-7 years. Pediatr Pulmonol 1998;25:322-31.

35. Buhr W, Jorres R, Berdel D, Landser FJ. Correspondence between forced oscillation and body plethysmography during bronchoprovocation with carbachol in children. Pediatr Pulmonol 1990;8:280-8.

36. Goldman MD, Carter R, Klein R, Fritz G, Carter B, Pachucki P. Within- and between-day variability of respiratory impedance, using impulse oscillometry in adolescent asthmatics. Pediatr Pulmonol 2002;34:312-9.

37. Beck KC, Offord KP, Scanlon PD. Bronchoconstriction occurring during exercise in asthmatic subjects. Am J Respir Crit Care Med 1994;149:352-7.

38. Delacourt C, Lorino H, Fuhrman C, et al. Comparison of the forced oscillation technique and the interrupter technique for assessing airway obstruction and its reversibility in children. Am J Respir Crit Care Med 2001;164:965-72.

39. Malmberg LP, Pelkonen A, Poussa T, Pohianpalo A, Haahtela T, Turpeinen M. Determinants of respiratory system input impedance and bronchodilator response in healthy Finnish preschool children. Clin Physiol Funct Imaging 2002;22:64-71.

40. Konig P, Hordvik NL, Pimmel RL. Forced random noise resistance determination in childhood asthma. Chest 1984;86:884-90. 


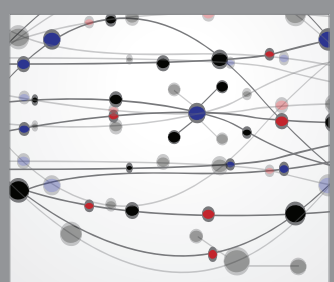

The Scientific World Journal
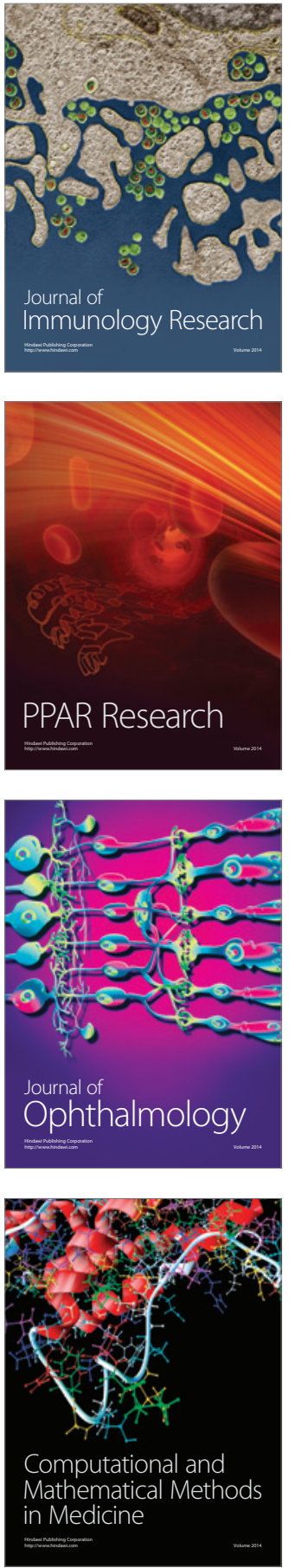

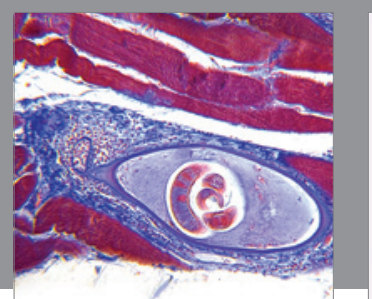

Gastroenterology Research and Practice

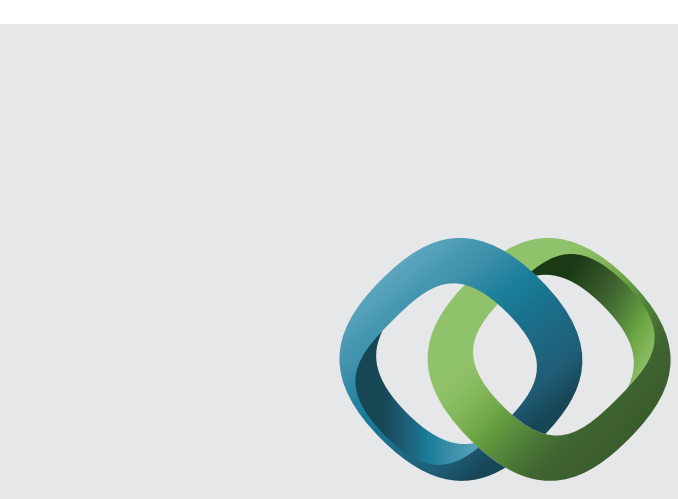

\section{Hindawi}

Submit your manuscripts at

http://www.hindawi.com
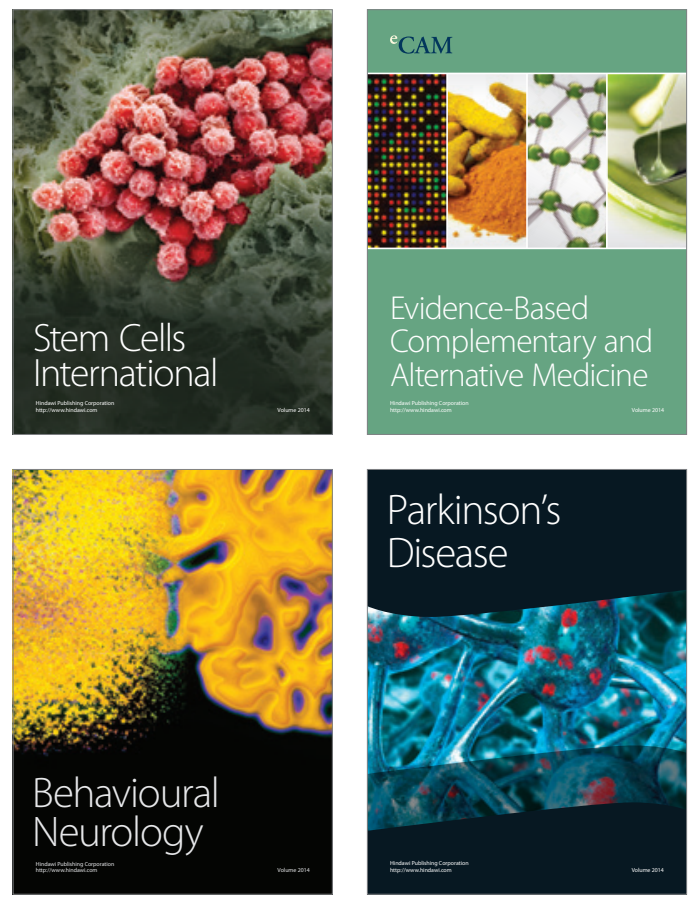
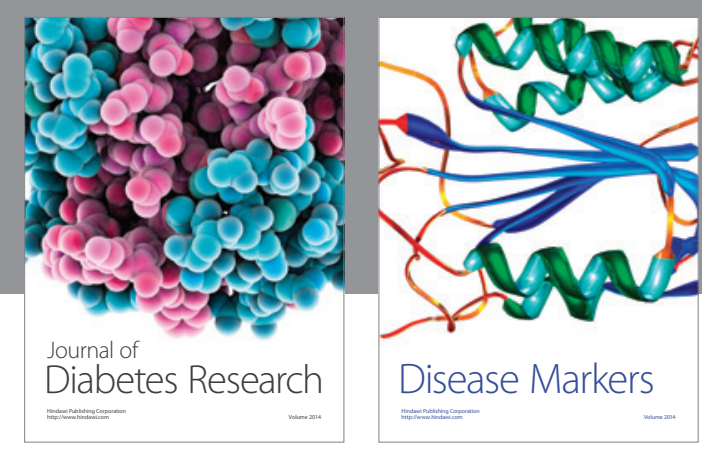

Disease Markers
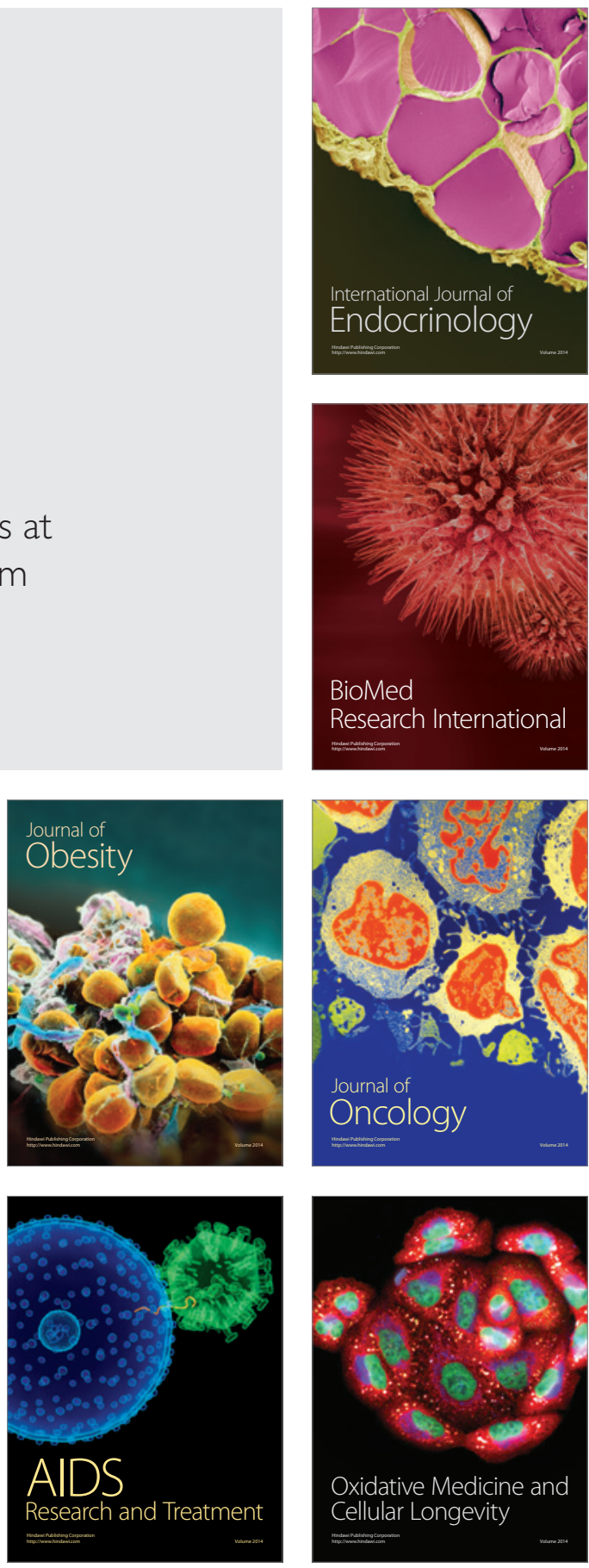